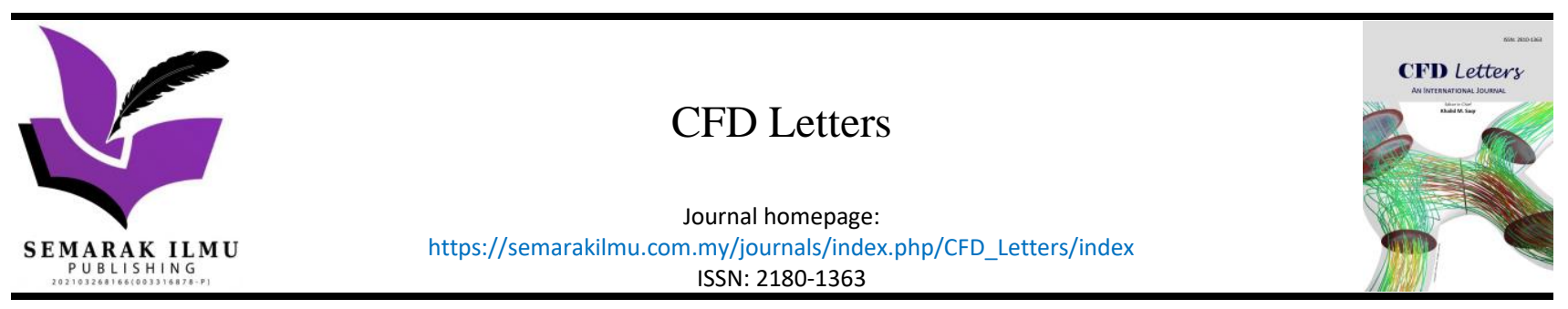

\title{
Study Reduction of Resistance on The Flat Hull Ship of The Semi-Trimaran Model: Hull Vane Vs Stern Foil
}

\author{
Rahmat Azis Nabawi ${ }^{1,}{ }^{*}$, Syahril $^{1}$, Primawati $^{1}$ \\ 1 Department of Mechanical Engineering, Faculty of Engineering, Universitas Negeri Padang, Padang, Sumatera Barat, Indonesia
}

ARTICLE INFO
ABSTRACT

\section{Article history:}

Received 29 August 2021

Received in revised form 12 November 2021

Accepted 13 November 2021

Available online 14 December 2021

\section{Keywords:}

Resistance; Efficiency energy, Hull Vane; Stern foil; CFD; Flat hull ship; Semitrimaran

\begin{abstract}
Flat hull ships is appraised for its superiority due to the manufacturing simplicity and lower investment costs, yet the ship has its own weakness for it requires a greater resistance. As a matter of fact, a significant reduction on the resistance can be done with foil installation but it is necessary to study the optimal position of the foil installation. This study is aimed at revealing the effectiveness of the Hull Vane and Stern Foil installation in reducing the resistance experienced by the flat hull ship of the semi-trimaran model. The research was conducted by comparing the resistance experienced by the flat hull ship of the semi-trimaran model without foil, Hull vane and Stern foil installations. In addition, the disclosure of resistance experienced by each ship model was carried out by using CFD simulation. The simulation results revealed that the installation of the Hull vane and Stern foil was able to reduce the resistance experienced by the flat hull ship of the semi-trimaran model. The largest reduction occurred in Froude number 1.1, where the Hull vane installation was able to reduce resistance by $12.44 \%$ and on the ship model with Stern foil installation the resistance reduction was $5.25 \%$. Based on the results of this CFD simulation, it can be concluded that the Hull Vane installation is more optimal in reducing resistance on the flat hull ship of the semi-trimaran model.
\end{abstract}

\section{Introduction}

Flat hull ship is a type of ship with low manufacturing costs which does not require high-tech equipment for the production process, the raw materials are easy to obtain and the production process is fast [1-3]. In addition, flat hull ships made of steel have a longer endurance than wooden ships and it is easier to maintain [4]. The flat hull ship has been manufactured with hull forms consisting of flat plates in straight line frames $[5,6]$, in which the whole plates for the hull are manufactured without undergoing the bending and the rollers process [7]. The analysis results of investment feasibility on the placement of flat hull ships as public shipping fleets, a net per cent value is obtained as $>0$, which means that this type of ship investment is in the feasible category [8]. Furthermore, the ships made of aluminium consume high-cost, the ships made of wood and composites are not environmentally friendly. The ships have short durability and high maintenance

\footnotetext{
* Corresponding author.

E-mail address: raazna@ft.unp.ac.id (Rahmat Azis Nabawi)
} 
costs [9]. Because of its simplicity, speed of production, and low cost of production, flat hull ships are very suitable for Indonesian citizens' shipping fleets of ships for emergency needs.

The flat hull ship of the semi-trimaran model has good stability and it is identified to be safe for sailing because it meets the IACS standards [10]. However, this flat hull ship of the semi-trimaran model has a greater resistance than the streamlined hull ships [11]. In ship design, resistance is a significant factor because it affects speed and fuel consumption [12, 13]. Additionally, the high consumption of fuel will increase gas emissions which have an impact on global warming [14]. Reducing fuel consumption to reduce gas emissions is very important in ship design [15]. Recently, many research are being conducted about ships with the topic of how to reduce resistance [16-18].

In general, the reduction of resistance can be done by optimizing the shape of the hull [19-21]. In addition, to reduce the resistance experienced by the ship significantly, it can be carried out by installing hydrofoil [21], and by using stern flaps [22]. The hydrofoil is an instrument designed to produce the lift force so that the fluid force on the hull is small [23]. In 1992, Peter Van Oossanen invented a hydrofoil mounted behind the transom and proved to be able to reduce ship resistance, this hydrofoil was named Hull vane [24]. At the bottom of the transom area, there are interceptors that can cause air vortices to generate the lift force [25]. The installation of Hull vane on cruise ships with a " $U$ " hull type using a NACA 4012 foil profile with an angle of attack of 0 degrees can limit the resistance at $22.9 \%$ [26]. In addition, the Naca 4012 foil with an angle of attack of 0 degrees mounted under the transom named Stern foil was able to reduce the resistance on the Mark VI patrol boat by 26.7\% [27-29].

According to the literature study, research on resistance in flat hull ships was recently published on the study of hull forms [30] and bow [1]. However, the research about the attempts to reduce resistance undergone by flat hull ships has not been conducted yet although the ship has been widely operated and it is potential to be developed due to its manufacturing simplicity and feasibility for investment. Likewise, there is no research being carried out about the installation of Hull vane and Stern foil for the flat hull ship of the semi-trimaran model. The application of hull vanes is also on ships with streamlined hull shapes, such as the TT-shaped, U-Shaped, and X-shaped [31]. Therefore, this research is intriguing to be conducted because there is still a gap to be researched. This study aims to reveal the impact of the installation of Hull vane and Stern foil in reducing the resistance of the flat hull ship of the semi-trimaran model and determining the most optimal foil between these two foils. The finding of this research will be very useful to be contributed for the development of science in the field of ship hydrodynamics, especially for the attempts to reduce resistance on flat hull ships and increase the number of literatures on the impact of Hull vane and Stern foil installations on resistance reduction. CFD simulations are carried out on Froude numbers 0.4 to 1.1. The Froude number values above 0.4 to 1.1 are for high-speed vessels [32], and there is only a little research have been conducted about the effect of Hull vane and Stern foil installations at these high speeds [27]. In addition to energy efficiency, the speed of the ship is also being pondered currently. Not only for military purposes but high-speed vessels are also required for public transportation because most passengers are more likely to choose a fast mode of transportation to reach their destination.

\section{Methodology}

\subsection{The Flat Hull Ship of Semi-trimaran}

The flat hull ship of semi-trimaran was the model for this research (Shown in Figure 1). This type of ship has been widely operated as a passenger ship, fishing boat and tourist ship in Indonesia. The main dimensions of this ship are provided in table 1 . The parameter ratios of the ship model: $L / B=$ $3.75, \mathrm{~B} / \mathrm{T}=3.29$, and $\mathrm{Cb}=0.49$. 
Table 1

Ship dimensions

\begin{tabular}{llll}
\hline Item & Ship & Model & Unit \\
\hline LoA & 12 & 0.9 & $\mathrm{~m}$ \\
$\mathrm{~B}$ & 3 & 0.225 & $\mathrm{~m}$ \\
$\mathrm{H}$ & 2.1 & 0.157 & $\mathrm{~m}$ \\
$\mathrm{~T}$ & 0.97 & 0.072 & $\mathrm{~m}$ \\
Displacement & 17609 & 7.3 & $\mathrm{~kg}$ \\
\hline
\end{tabular}

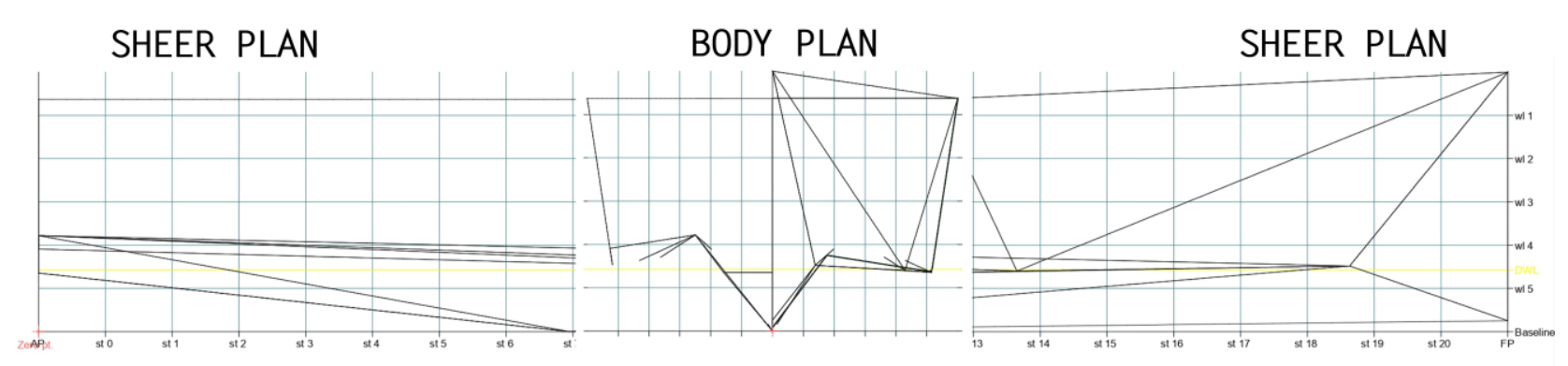

HALFBREADTH PLAN

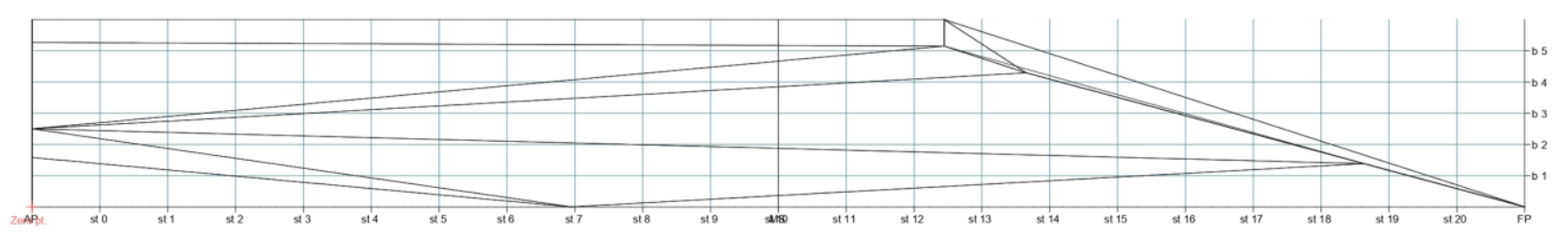

Fig. 1. Line plan of the flat hull ship of semi-trimaran model

\subsection{Research Procedure}

This research was conducted by method the computer fluid dynamics (CFD) using the Solidworks 2021-2022 Research License. The foil profile used the NACA 4012 type with an angle of attack of 0 degrees and the dimensions of the foil stretch were made the same length as the width of the ship. Furthermore, the research variables were the flat hull ship of the semi-trimaran model without foil (Figure. 2.a), Hull vane installation (Figure. 2.b) and Stern foil installation (Figure. 2.c).

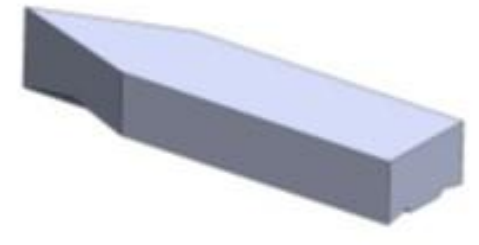

(a)

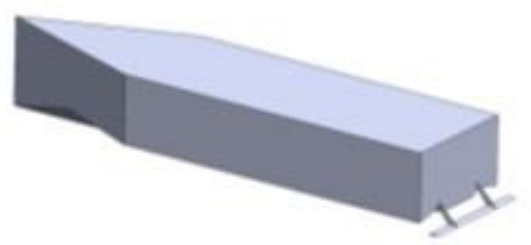

(b)

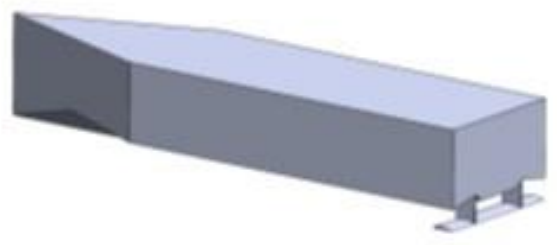

(c)

Fig. 2. The Flat hull ship Semi-Trimaran model (a) without foil (b) Hull vane installation (c) Stern foil installation

The position and dimensions of the foil for the ship model with the Hull vane installation referred to the study [26], as displayed in Figure 3.b Cord dimensions for Hull vane LWL/50 $=18 \mathrm{~mm}$. Further, the position and dimensions of the foil for the ship model with the Stren Foil installation referred to the research [28], in which the cord dimensions in this research were designed with a trial-and-error 
process. Viewed from the comparison of LWL with the ship model using a ratio $L W L / 25$. In this study, the ship model with Stern foil installation used a $36 \mathrm{~mm}$ cord dimension (Figure 3. b).

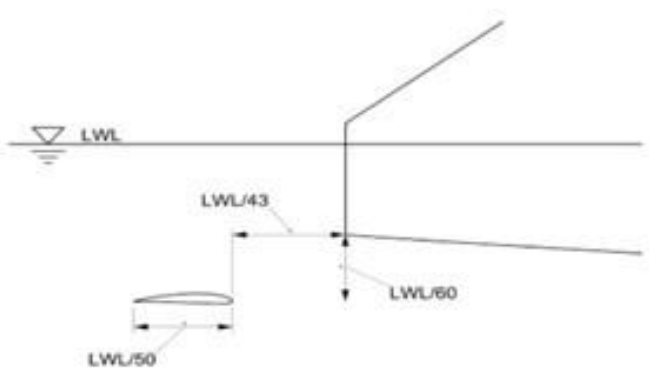

(a)

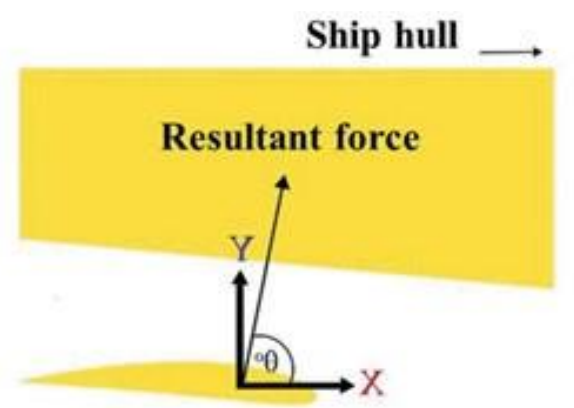

(b)

Fig. 3. (a) Hull vane ${ }^{\circledR}$ configuration [26] (b) Stern foil configuration [28]

The effectiveness of the Hull vane is inseparable from the shape of the lower hull in the transom area, where the stern area must be shallower than the mid hull. In addition, this configuration causes the flow under the hull to incline upwards instead of being horizontal (Figure 4) [31]. In this case, the flow will trigger two sorts of forces on the foil, these are a lift force that lifts the stern of the ship (reduced running trim) and a drag force (much smaller). These two forces simultaneously form a resultant force that pushes the ship forward (forward force) [33]. The Hull vane dampens vessel motions such as pitching and yawing while sailing in waves and therefore reduces the additional resistance caused by these motions [34].

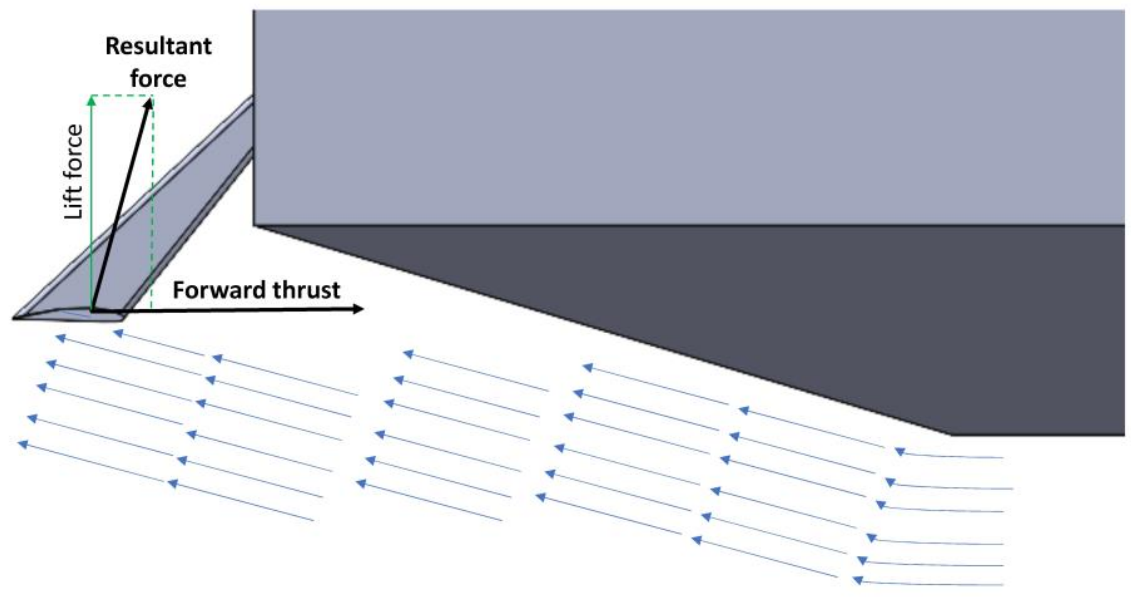

Fig. 4. Working principles of Hull vane and configuration of stern area

\subsection{CFD Simulation}

CFD is a simulation method for visualizing, predicting and evaluating fluid flow in various engineering applications. Due to the advances in computational technology, the ship resistance can be calculated more accurately using the CFD method [35-37]. Furthermore, accurate calculation of ship resistance is an important factor for designing ship propulsion systems [13]. When the ship was moving, a contact with two types of fluids occurred in the submerged hull with water and in the upper hull with air. Additionally, these two fluids did not mix, therefore the CFD analysis needed to be modelled using the Volume of Fluid (VOF) technique which was able solve a set of momentum equations and track the volume fraction in each fluid throughout the domain. The VOF is generally 
used on free surfaces with two types of fluids and boundary conditions are used to simulate flow near the model to calculate resistance [16]. The volume fraction in both fluids was added together by using Eq. (1).

$$
\sum_{q=0}^{N_{q}-1} \alpha_{q}=1
$$

The basic concept of the VOF method was the fluid volume fraction $q(q=0 . . N q-1)$ in which the value must be between 0 and 1 . In these two fluid concepts, mesh cells in the water $0=0$ and $1=1$, while mesh cells in the air $0=1$ and $1=0 . \mathrm{Nq}$ was the amount of mixed fluid. The volume fraction used Eq. (2).

$\frac{\partial \alpha_{q}}{\partial t}+\frac{\alpha_{q}}{\rho_{q}} \frac{\partial \rho_{q}}{\partial t}+\sum_{i} \frac{\partial \alpha_{q} u_{i}}{\partial x_{i}}=0$

As a result of the volume fraction equation, the law of conservation of mass had Eq. (3).

$$
\sum_{q=0}^{N_{q-1}}\left(\frac{\alpha_{q}}{\rho_{q}} \frac{\partial \rho_{q}}{\partial t}\right)+\sum_{i} \frac{\partial u_{i}}{\partial x_{i}}=0
$$

Furthermore, momentum, density, diffusion, convention surface and mass force used Eq. (4) and the energy equation can be was written as follows, Eq. (5).

$$
\begin{gathered}
\frac{\partial u_{i}}{\partial t}+\rho u_{i} \sum_{q=0}^{N_{q}-1}\left(\frac{\alpha_{q}}{\rho_{q}} \frac{\partial \rho_{q}}{\partial t}\right)+\rho \sum_{j} \frac{\partial}{\partial x_{j}}\left(u_{i} u_{j}\right)+\frac{\partial p}{\partial x_{i}}=\sum_{j} \frac{\partial}{\partial x_{j}}\left(\tau_{i j}+\tau_{i j}^{R}\right)+S_{i} \quad i=0,1,2 \\
\frac{\partial H}{\partial t}+\rho H \sum_{q=0}^{N_{q}-1}\left(\frac{\alpha_{q}}{\rho_{q}} \frac{\partial \rho_{q}}{\partial t}\right)+\rho \sum_{i} \frac{\partial u_{i} H}{\partial x_{i}} \sum_{i j} \frac{\partial}{\partial x_{j}}\left(u_{j}\left(\tau_{i j}+\tau_{i j}^{R}\right)+q_{i}\right)+\frac{\partial p}{\partial t}-\sum_{i j} \tau_{i j}^{R} \frac{\partial u_{i}}{\partial x_{j}}+p \varepsilon \\
+\sum_{i} S_{i} u_{i}+\mathcal{Q}_{H}
\end{gathered}
$$
(6).

$h=\sum_{q=0}^{N_{q-1}} \frac{h_{q} \alpha_{q} \rho_{q}}{\rho}$

In addition, other fluid properties such as heat conductivity (Eq. 7), viscosity (Eq. 8) and heat capacity (Eq. 9) were defined in the same way. 
$\lambda=\sum_{q=0}^{N_{q}-1} \alpha_{q} \lambda_{q}$

$\mu=\sum_{q=0}^{N_{q}-1} \alpha_{q} \mu_{q}$

$C_{p} \sum_{q=0}^{N_{q-1}} \frac{\alpha_{q} \rho_{q}}{\rho} C_{p, q}$

The total resistance $\left(R_{T}\right)$ consisted of two components called the frictional resistance $\left(R_{F}\right)$ and residual resistance $\left(R_{R}\right)$, Eq. (10).

$R_{T}=R_{F}+R_{R}$

The residual $\left(R_{R}\right)$ was the sum of the viscous pressure resistance $\left(R_{V P}\right)$ and the wave-making resistance $\left(R_{w}\right)$, Eq. (11).

$R_{R}=R_{V P}+R_{W}$

Velocity parameters in CFD computations were similar to physical experiments using Froude numbers, Eq. (12):

$F r=\frac{V}{\sqrt{g L p p}}$

Parameters of the condition of simulation using the free surface are shown in table 2.

Table 2

Parameter condition of simulation

\begin{tabular}{lcl}
\hline Analysis type & External \\
\hline Consider closed cavities & - & Exclude cavities without flow conditions \\
Time-dependent & - & Exclude internal space \\
& - & Total analysis time: $60 \mathrm{sec}$. \\
Gravity & - & output time step: $1 \mathrm{sec}$. \\
Flow analysis type & Y component: $-9.81 \mathrm{~m} / \mathrm{s}^{2}$ \\
Two immiscible fluids & Free surface \\
& $-\quad$ Air \\
Velocity parameters & Velocity in X direction \\
Boundary Condition & $-\quad$ Inlet: Velocity with define Froude Number \\
& $-\quad$ Outlet: Constant \\
& $-\quad$ Wall: No-slip condition \\
& $-\quad$ Hull and Hull Vane: No-slip condition \\
\hline
\end{tabular}

The computational domain was organized according to the International Towing Tank Conference (ITTC) for CFD [38], as shown in figure 5. Ship models, foil and wall were defined as the no-slip 
condition. The inlet boundary was defined as the fluid inlet and the fluid flow velocity was equivalent to the ship speed. Moreover, the inlet boundary was located upstream at a distance of 1-L from the bow of the ship ( $L$ was the length of the waterline). The outlet boundary was located downstream at a distance of 2-L from the transom. The outlet was an open boundary so the pressure was not compressed and the pressure was constant. Furthermore, the lower wall was located 1-L from the keel and the upper wall was $0.25-\mathrm{L}$ from the deck. The sidewall was located $1-\mathrm{L}$ from the longitudinal axis.

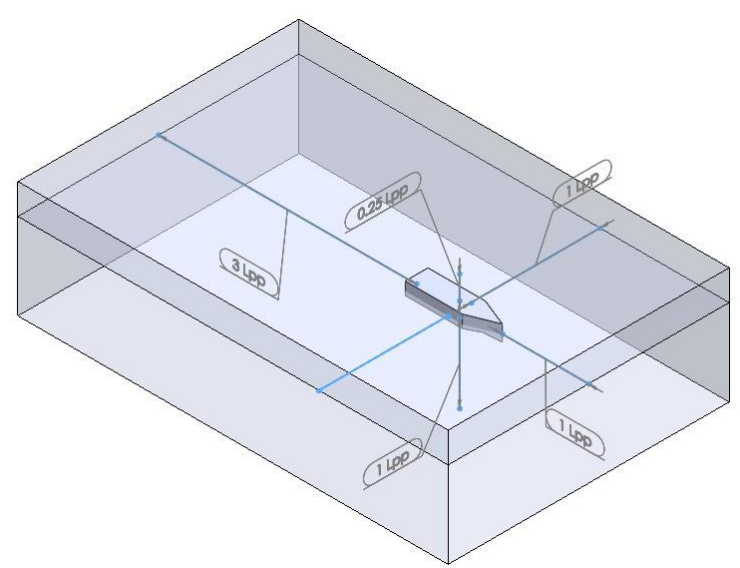

Fig. 5. Computational Domain

\section{Results}

\subsection{Validation and Verification of CFD Simulation}

Data validation of CFD simulation results was carried out by comparing it with the experimental test results. Based on the study, the results of the CFD simulation that are compatible with the results of towing tank experiments are miniscule mesh sizes with a total cell of the fine is $2.5 \mathrm{M}$ [26]. Moreover, the mesh number is $\pm 350,000$ with a computing time of 24 to 25 hours which is categorized as the best quality and close to the experimental results [29]. In this study, the total cells were $3.4 \mathrm{M}$ while in the Foil area, the mesh used was further refined to capture the flow more accurately (Figure 6). Hence, the large grid space was used near the boundaries to prevent the wave reflection from occurring [38].

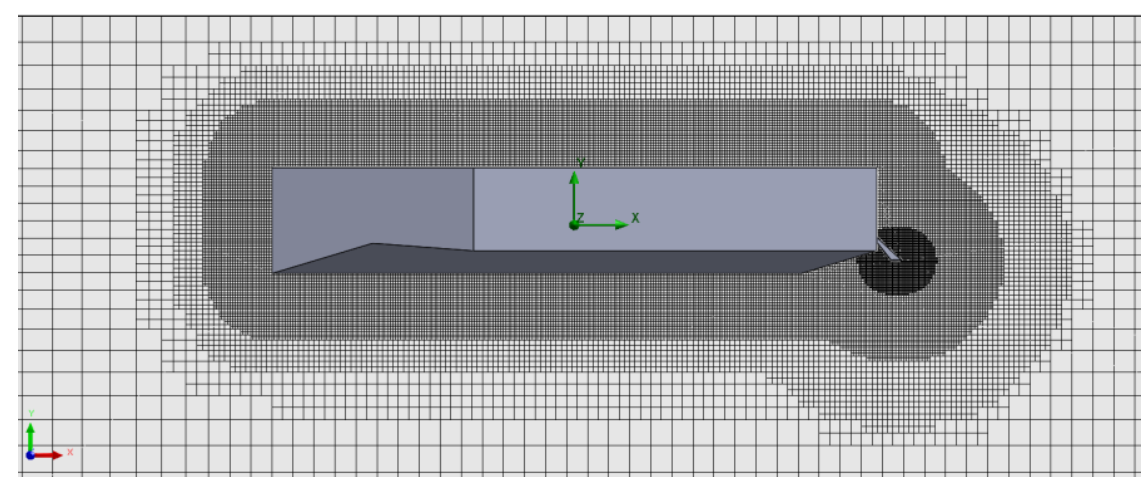

Fig. 6. Detail of CFD mesh employed in this study

The verification of the data from the CFD analysis was conducted by checking the convergence. In CFD analysis, there was a term called iteration which meant as a process of repeated calculations to achieve convergence so the results of the analysis was categorized to be accurate and valid. 
Additionally, accurate results were indicated by the residual or the difference in the calculation results between the first and subsequent iterations had to be as small as possible to approach zero (normalized scale $0 \sim 1$ ). Moreover, the accuracy and optimality of the simulation results in this study were shown in each set goal marked with "Achieved $(I T=\ldots)$ ", and these results were obtained at the completion of each CFD simulation in each ship model (Figure 7).

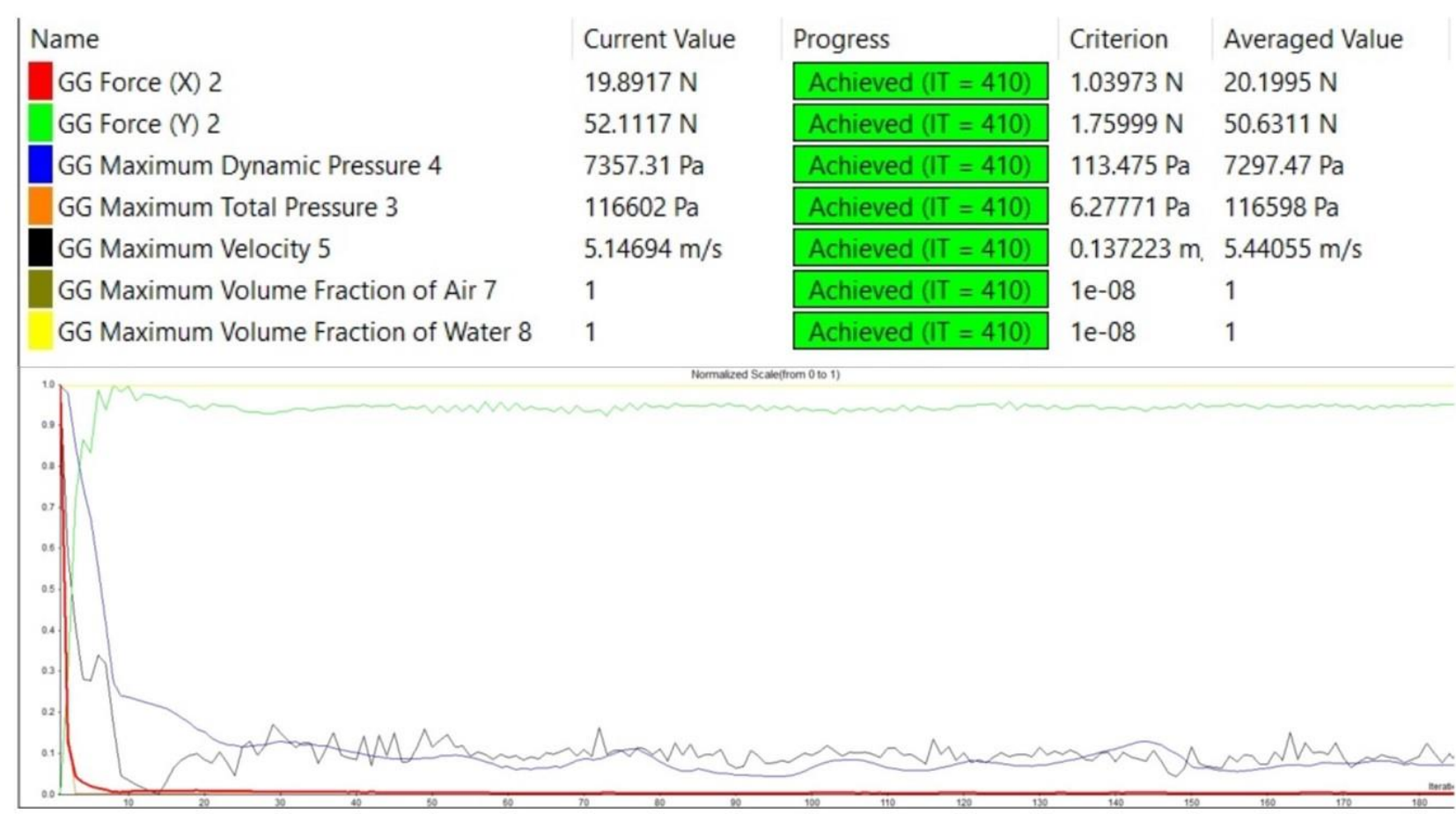

Fig. 7. Iteration monitoring windows

\subsection{Comparison of Resistance of Each Ship Model}

Figure 8 displays a comparison chart of the resistance experienced by each ship model with variations in the Froude number. Based on the results of the CFD simulation, it can be concluded that the installation of the Hull vane and Stern foil was able to reduce the resistance undergone by the semi-trimaran flat hull ship model. Further, the CFD simulation results revealed that the greater the Froude number or the faster the ship's speed, the greater the reduction in resistance due to the installation of the Hull vane and stern foil. At each Froude number (0.4 to 1.1), the resistance undergone by ships using hull vanes was found smaller than the ships using stern foil. A significant reduction in resistance occurred in Froude number 1.1, where the Hull vane installation was able to reduce resistance by $12.44 \%$, while the ship model with Stern foil installation reduced resistance by $5.25 \%$. Judging from the effectiveness of reducing resistance, Hull vane installation was appraised to be superior compared to Stern Foil. Thus, the findings of this research are consistent with other studies where the installation of Hull vane or the position of the foil after transom produce excellent quality in reducing resistance than Stern foil whose foil position is under the transom [29]. 


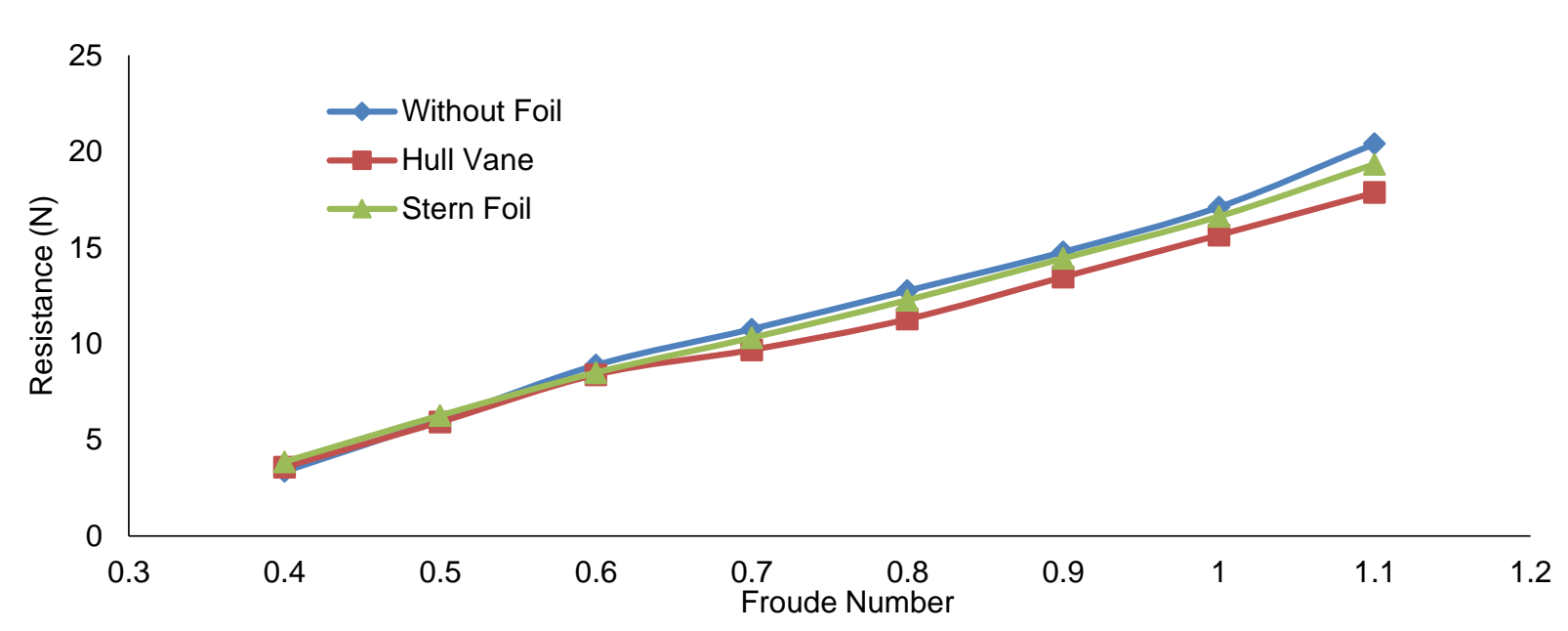

Fig. 8. The resistance comparison of each ship model

\subsection{Flow Velocity after Transom on Each Ship Model}

As a matter of fact, the CFD simulation did not only produce the resistance data experienced by the ship, but it also observed the velocity and turbulence of the flow that occured. Figure 9 displays the flow velocity comparison after transom in Froude number 1.1. Hence, there were differences found in flow velocity after transom from each ship model. In addition, the ship model with Hull vane installation was also observed and it showed the less low flow velocity after transom than the ship without foil and Stern foil installation (low flow velocity was marked in blue, light blue and green). The low flow velocity after transom on ships without a Hull vane was caused by the most of the 'dead water' being dragged away by the ship, as the depth of the transom increased [39]. On ships with a Hull vane application, the flow behind the stern is seen to be faster. This indicates that there is a reduction in the stern wave generated by the ship.

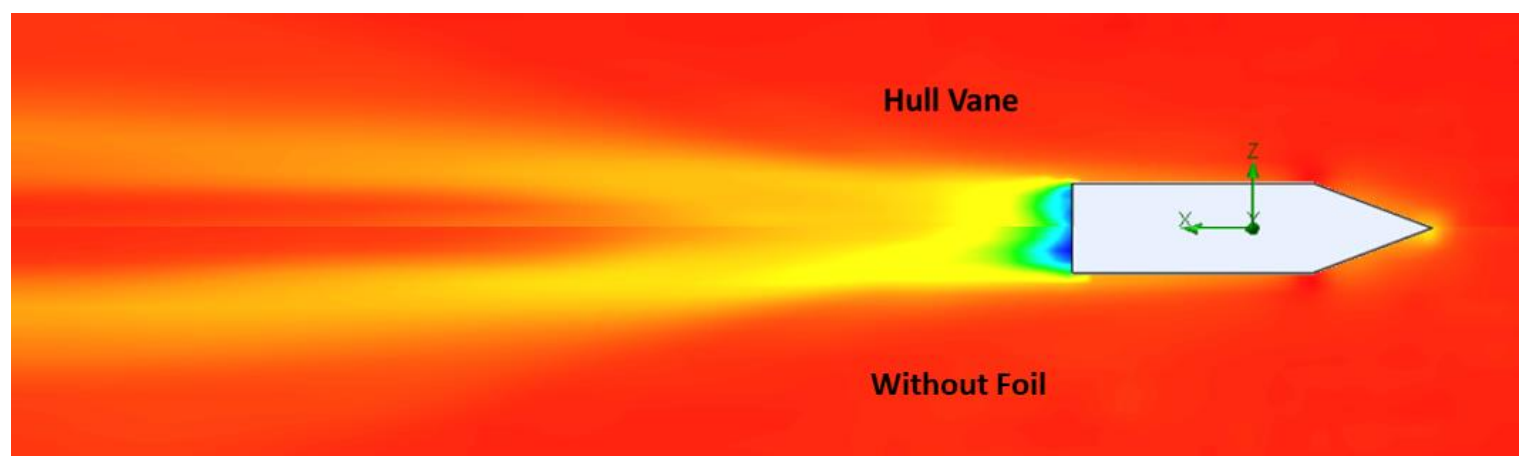

(a)

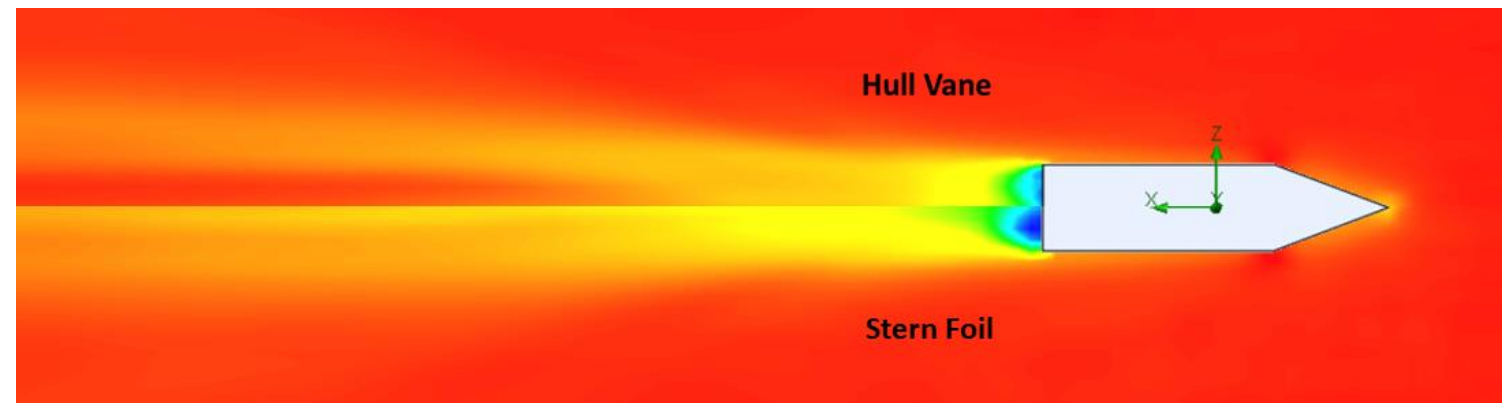

(b) 


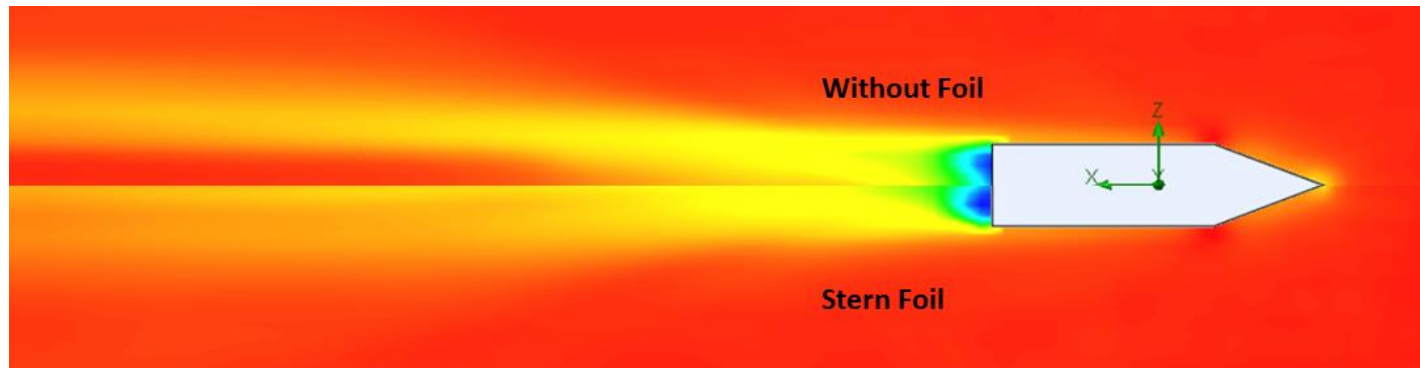

(c)

Fig. 9. The Comparison of flow rates after transom at Froude number 1.1 (a) Hull vane Vs Without foil (b) Hull vane Vs Stern foil and (c) Without foil VS Stern foil

\subsection{Turbulence Intensity of Flow after Transom on Each Ship Model}

In addition, the low flow behind the transom on the flat hull ship of semi-trimaran model without foil indicated the occurrence of flow disturbance or turbulence which meant that the wave-making resistance occured. The same issue also happened to the ship model with Stern foil installation in which that turbulence was still occurring which indicated that the wave-making resistance was still large. In addition, the ship model with Hull vane installation showed the occurrence of fast flow after the transom which minimalised the heavy turbulence. The results of this simulation are in line with research on the application of Hull vane to Holland Claas OPVs, where on the ship model without Hull vane installation, flow turbulence called backflow towards the transom occurs and the Hull vane installation causes the length of the turbulence zone behind the transom decreases [39]. In experimental research, visual data was also obtained from the waves occurring after the transom in which the waves were smoother on the ships with Hull vane installation, while ships without Hull vane showed severe turbulent waves [40]. Furthermore, Hull vane transmitted the fluid flow so there was no backflow to the transom. Hull vane installation reduced wave-making resistance, which was the largest percentage in total resistance reduction [26]. Captured the turbulence intensity after transom of each ship model shown in Figure 10.

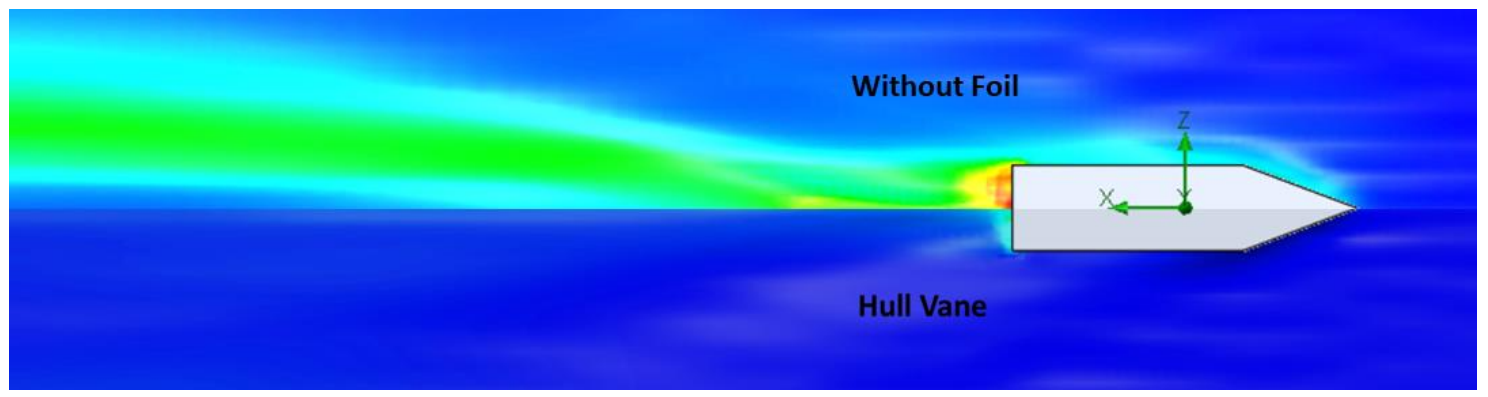

(a)

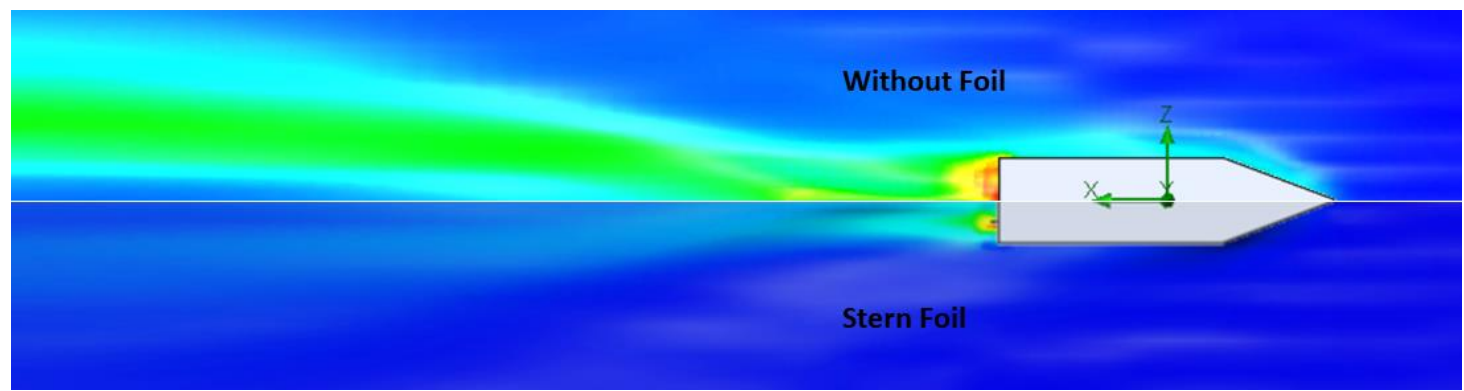

(b) 


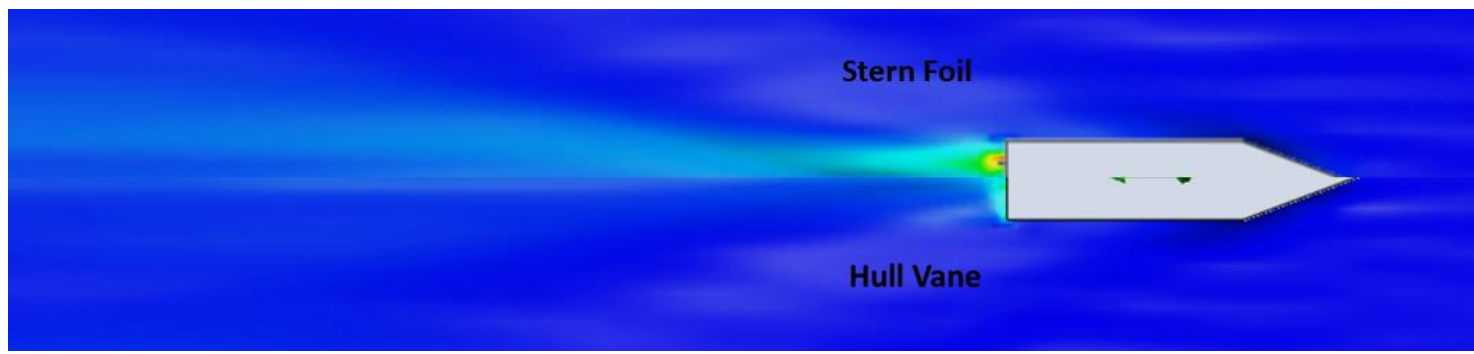

(c)

Fig. 10. The Comparison of turbulance intensity after transom at Froude number 1.1 (a) Without foil Vs Hull vane (b) Without foil Vs Stern foil and (c) Stern foil Vs Hull vane

\section{Conclusions}

The research about reducing resistance the flat hull ship of the semi-trimaran model is important to be conducted since this type of ship is suitable for public shipping fleets and emergency ships. The amount of resistance will affect the engine used and the amount of fuel consumption. According to the results of the CFD simulation that has been carried out, it can be concluded that the installation of Hull vane and Stern foil can reduce the resistance experienced by the flat hull ship of the semitrimaran model. In sum, the biggest reduction occurred in Froude number 1.1. The simulation results reveal that the ship model using Stern Foil installation still experiences heavy turbulence near the transom which indicates that the ship's wave-making resistance is still huge. While the ship model with Hull vane installation shows the occurrence of fast flow behind the transom. Hull vane transmits the fluid flow so the reduction of backflow to the transom causes turbulence. The fast flow behind the ship with the application of a Hull vane indicates the low waves generated by the ship. Based on the effectiveness in reducing resistance, the Hull vane installation is more optimal than the Stern foil installation.

\section{Acknowledgement}

The authors would like to thank Lembaga Penelitian dan Pengabdian Masyarakat Universitas Negeri Padang for funding this work with a contract number: 909/UN35.13/LT/2021.

\section{References}

[1] Syahril, Syahril, and Rahmat Azis Nabawi. "Numerical Investigation of the effect on Four Bow Designs Flat Hull Ship." International Journal of Geomate (Geotechnique, Construction Materials and Environment) 17, no. 62 (2019): 231-236. https://doi.org/10.21660/2019.62.95333

[2] Tresno, $\mathrm{H}$ and Albert, M. "Pengembangan Desain Kapal Lambung Pelat Datar," in Seminar Nasional Tahunan Teknik Mesin (SNTTM) ke-9, pp. 13-15, (2010).

[3] Nabawi, R. A., Syahril, \& Salmat. Stability study of flat hull ship for fishing tourism. Teknomekanik. Vol.3, No. 2 (2020): 75-80. https://doi.org/10.24036/teknomekanik.v3i2.9272

[4] Astiti, T. W. "Revitalisasi armada pelayaran rakyat dengan menggunakan kapal baja lambung pelat datar," Undergraduate Thesis, Universitas Indonesia, (2015).

[5] Jay, Dev. "Jag Dev, First Pioneer Ship to enter service." Shipping World and Shipbuilder. 161, (3882) (1968).

[6] Gallin, C. "Investigation in Ship Design," Transactions of the North East Coast Institution of Engineer and Shipbuilders. 94, 17 (1977-1978).

[7] Harvard, SV. AA. Resistance and Propulsion of Ships. Canada: Joh Wiley \& Sons, (1983).

[8] Guswondo, D. "Analisa kelayakan investasi kapal lambung pelat rata sebagai armada pelayaran rakyat," Undergraduate Thesis, Universitas Indonesia, (2009).

[9] Bich, Vu Ngoc, Nguyen Thi Ngoc Hoa, and Nguyen Ngoc Tuan. "Perspective of Environment-Friendly Materials in Small Boats Manufactured in Vietnam." Int. J. Mech. Eng. App/3, no. 1 (2015): 29-33. https://doi.org/10.11648/i.ijmea.s.2015030301.15 
[10] Putra, G. L, Wibowo, H. T and Agusta, F. "Stability analysis of semi-trimaran flat hull ship for a sea transportation model." Communications in Science and Technology 2, no. 2 (2017). 42-46. https://doi.org/10.21924/cst.2.2.20152

[11] Budiyanto, M. A, Tresno, H and Fattah, M. "Perbandingan nilai hambatan kapal antara hasil simulasi dengan eksperimen pada kapal pelat datar semi-trimaran," in Prosiding SNTTM XVI, 2017, pp. 168-171.

[12] Riesner, $M$ and Moctar, O. e. "A time domain boundary element method for wave added resistance of ships taking into account viscous effects." Ocean $\quad$ Engineering $162 \quad$ (2018): $290-303$. https://doi.org/10.1016/i.oceaneng.2018.05.010

[13] Niklas, Karol, and Hanna Pruszko. "Full scale CFD seakeeping simulations for case study ship redesigned from Vshaped bulbous bow to X-bow hull form." Applied Ocean Research 89 (2019): $188-201$. https://doi.org/10.1016/i.apor.2019.05.011

[14] Song, Soonseok, Yigit Kemal Demirel, Claire De Marco Muscat-Fenech, Tahsin Tezdogan, and Mehmet Atlar. "Fouling effect on the resistance of different ship types." Ocean Engineering 216 (2020): 107736. https://doi.org/10.1016/i.oceaneng.2020.107736

[15] Hizir, Olgun, Mingyu Kim, Osman Turan, Alexander Day, Atilla Incecik, and Yongwon Lee. "Numerical studies on non-linearity of added resistance and ship motions of KVLCC2 in short and long waves." International Journal of Naval Architecture and Ocean Engineering 11, no. 1 (2019): 143-153. https://doi.org/10.1016/j.ijnaoe.2018.02.015

[16] Budiyanto, Muhammad Arif, Muhamad Fuad Syahrudin, and Muhammad Aziz Murdianto. "Investigation of the effectiveness of a stern foil on a patrol boat by experiment and simulation." Cogent Engineering 7, no. 1 (2020): 1716925. https://doi.org/10.1080/23311916.2020.1716925

[17] Peng, Heather, Shaoyu Ni, and Wei Qiu. "Wave pattern and resistance prediction for ships of full form." Ocean Engineering 87 (2014): 162-173. https://doi.org/10.1016/i.oceaneng.2014.06.004

[18] Campana, Emilio Fortunato, Matteo Diez, Giampaolo Liuzzi, Stefano Lucidi, Riccardo Pellegrini, Veronica Piccialli, Francesco Rinaldi, and Andrea Serani. "A multi-objective DIRECT algorithm for ship hull optimization." Computational optimization and applications 71, no. 1 (2018): 53-72. https://doi.org/10.1007/s10589-017-9955-0

[19] Diez, M., A. Serani, E. F. Campana, and F. Stern. "CFD-based stochastic optimization of a destroyer hull form for realistic ocean operations." In FAST. 2017.

[20] Jung, Yoo-Won, and Yonghwan Kim. "Hull form optimization in the conceptual design stage considering operational efficiency in waves." Proceedings of the Institution of Mechanical Engineers, Part M: Journal of Engineering for the Maritime Environment 233, no. 3 (2019): 745-759. https://doi.org/10.1177/1475090218781115

[21] Vellinga, Ray. Hydrofoils: Design, Build, Fly. Peacock Hill Publishing, 2009.

[22] Song, Ke-wei, Chun-yu Guo, Jie Gong, Ping Li, and Lian-zhou Wang. "Influence of interceptors, stern flaps, and their combinations on the hydrodynamic performance of a deep-vee ship." Ocean Engineering 170 (2018): 306-320. https://doi.org/10.1016/j.oceaneng.2018.10.048

[23] Besnard, Eric, Adeline Schmitz, George Tzong, Kalle Kaups, and Hamid Hefazi. Hydrofoil Design and Optimization for Fast Ships. CALIFORNIA STATE UNIV LONG BEACH DEPT OF AEROSPACE ENGINEERING, 1998.

[24] Andrews, Iruthayaraju, Venkata Karthik Avala, Prasanta K. Sahoo, and Sudarshanaram Ramakrishnan. "Resistance characteristics for high-speed hull forms with vanes." In SNAME 13th International Conference on Fast Sea Transportation. OnePetro, 2015. https://doi.org/10.5957/FAST-2015-012

[25] Avci, Ahmet Gultekin, and Baris Barlas. "An experimental investigation of interceptors for a high speed hull." International Journal of Naval Architecture and Ocean Engineering 11, no. 1 (2019): $256-273$. https://doi.org/10.1016/i.ijnaoe.2018.05.001

[26] Celik, C., D. B. Danisman, P. Kaklis, and S. Khan. "An investigation into the effect of the Hull Vane on the ship resistance in OpenFOAM." In Sustainable Development and Innovations in Marine Technologies, pp. 136-141. CRC Press, 2019. https://doi.org/10.1201/9780367810085

[27] Budiyanto, Muhammad Arif, Muhammad Aziz Murdianto, and Muhamad Fuad Syahrudin. "Study on the Resistance Reduction on High-Speed Vessel by Application of Stern Foil Using CFD Simulation." CFD Letters 12, no. 4 (2020): 35-42. https://doi.org/10.37934/cfdl.12.4.3542

[28] Budiyanto, Muhammad Arif, Muhamad Fuad Syahrudin, and Muhammad Aziz Murdianto. "Investigation of the effectiveness of a stern foil on a patrol boat by experiment and simulation." Cogent Engineering 7, no. 1 (2020): 1716925. https://doi.org/10.1080/23311916.2020.1716925

[29] Budiyanto, M A, Naufal Yudha Prawira, and Haekal Dwiputra. "Lift-to-Drag Ratio of the Application of Hydrofoil with Variation Mounted Position on High-Speed Patrol Vessel." CFD Letters 13, no. 5 (2021): 1-9. https://doi.org/10.37934/cfdl.13.5.19

[30] Afriansyah, N., A. B. B., \& Rindo, A. Studi desain Analisa perbandingan performace kapal perintis 750 DWT dengan variasi hull menggunakan pelat datar. Jurnal Teknik Perkapalan. Vol 6, No.1 (2018):160-167. 
[31] Ferreé, H., Goubault, P., Yvin, C. \& Bouckaert, B. Improving the nautical performance of a surface ship with the Hull $V{ }^{\circledR}{ }^{\circledR}$ appendage. Association Technique Maritime et Aéronautique. Numéro: 2738. 2019.

[32] Van Oossanen, Piet. "Resistance prediction of small high-speed displacement vessels: state of the art." International Shipbuilding Progress 27, no. 313 (1980): 212-224.

[33] Bouckaert, B. "An underwater spoiler on a warship: why, when and how?". Zeszyty Naukowe Akademii Marynarki Wojennej. Vol. 214, No. 3 (2018). 5-23. https://doi.org/10.2478/sipna-2018-0016

[34] Bouckaert, Bruno. "An underwater spoiler on a warship: why, when and how?." Zeszyty Naukowe Akademii Marynarki Wojennej 59 (2018).

[35] Demirel, Yigit Kemal, Osman Turan, and Atilla Incecik. "Predicting the effect of biofouling on ship resistance using CFD." Applied Ocean Research 62 (2017): 100-118. https://doi.org/10.1016/i.apor.2016.12.003

[36] Song, Soonseok, Yigit Kemal Demirel, and Mehmet Atlar. "An investigation into the effect of biofouling on the ship hydrodynamic characteristics using $\quad$ CFD." Ocean $\quad$ Engineering $175 \quad$ (2019): $122-137$. https://doi.org/10.1016/i.oceaneng.2019.01.056

[37] Farkas, Andrea, Soonseok Song, Nastia Degiuli, Ivana Martić, and Yigit Kemal Demirel. "Impact of biofilm on the ship propulsion characteristics and the speed reduction." Ocean Engineering 199 (2020): 107033. https://doi.org/10.1016/j.oceaneng.2020.107033

[38] ITTC. "Practical guidelines for ship resistance CFD." ITTC-Recomm. Proced. Guidel. 27th (2014): 1-9.

[39] Bouckaert, Bruno, Kasper Uithof, Perry van Oossanen, Niels Moerke, Bart Nienhuis, and Jan van Bergen. "A lifecycle cost analysis of the application of a Hull Vane to an Offshore Patrol Vessel." In SNAME 13th International Conference on Fast Sea Transportation. OnePetro, 2015. https://doi.org/10.5957/FAST-2015-028

[40] Hou, Hongbo, Mateusz Krajewski, Y. Kaan Ilter, Sandy Day, Mehmet Atlar, and Weichao Shi. "An experimental investigation of the impact of retrofitting an underwater stern foil on the resistance and motion." Ocean Engineering 205 (2020): 107290. https://doi.org/10.1016/i.oceaneng.2020.107290 